\title{
LHD サブクール冷却システムの特性
}

\author{
尾花 哲浩 ${ }^{\dagger}$, 濱口 真司, 柳 長門, 三戸 利行 \\ 森内 貞智, 関口 温朗, 大場 恒揮, 今川 信作
}

\section{Characteristics of the LHD Subcooling System}

\author{
Tetsuhiro OBANA ${ }^{\dagger}$, Shinji HAMAGUCHI, Nagato YANAGI, Toshiyuki MITO \\ Sadatomo MORIUCHI, Haruo SEKIGUCHI, Koki OBA and Shinsaku IMAGAWA
}

\begin{abstract}
Synopsis: The cooling system for the helical coils of the Large Helical Device (LHD) was upgraded in 2006 in order to improve the stability of the LHD helical coils. The cooling system that has 20 parallel paths to provide subcooled He to the helical coils fulfills the following design requirements: inlet temperature of $3.2 \mathrm{~K}$ and mass flow rate for the coils of $50 \mathrm{~g} / \mathrm{s}$. Although the system meets these requirements, the characteristics of the system are not understood in practice. In this study, the influences of the mass flow rate and cooling temperature on the cooling system were investigated to determine what is required for stable system operation. The results show that the temperatures at each position changed linearly with the temperature of the supplied subcooled $\mathrm{He}$; and that an unstable state in the parallel paths occurred when the mass flow rate decreased. A mass flow rate of at least $30 \mathrm{~g} / \mathrm{s}$ is needed to prevent an unstable state in the cooling system when subcooled He of $3.2 \mathrm{~K}$ is supplied to the helical coils. In addition, the temperature of the helical coil winding was evaluated using a numerical calculation, in which the numerical model simplifying the helical coil configuration was utilized. This was done because the helical coil winding is not equipped with thermometers in terms of electrical insulation. Using the numerical model, the temperatures at the coil outlet and coil case can be predicted not only under a steady heat load, but also under coil excitation. The coil winding temperature is close to the coil outlet temperature under coil excitation because of AC loss.
\end{abstract}

Keywords: Large helical device (LHD), helical coil, pool-cooled superconducting coil, subcooled $\mathrm{He}$

\section{1.はじめに}

大型ヘリカル装置 (LHD) の超伝導ヘリカルコイルでは、 更なる高磁場化を実現するために、ヘリカルコイルヘの供 給冷媒温度を低下させて冷却安定性を改善する『サブクー ル冷却改造』を2006 年度に実施した ${ }^{1,2)}$ 。その結果、改造 時の目標值である温度 $3.0 \mathrm{~K}$ 、流量 $50 \mathrm{~g} / \mathrm{s}$ のサブクール液体 ヘリウムをヘリカルコイルヘ供給することが可能となり、 改造した冷却システムが所定の性能を満足することが分か った 3)。しかしながら、長期的に安定な連続運転を可能に するためには、様々な条件下での泠却システムの特性を十 分に把握する必要がある。そこで、定常熱負荷下における 冷却特性を理解するための流動冷却試験、及びヘリカルコ イル励磁時の交流損失による冷却システムへの影響を検証 するためのコイル通電試験を行った。また、実測すること が困難なヘリカルコイル巻線部の温度を、ヘリカルコイル

Received March 24, 2009

自然科学研究機構 核融合科学研究所

于509-5292 岐阜県土岐市下石町 322-6

National Institute for Fusion Science, 322-6 Oroshi-cho, Toki, Gifu 509-5292, Japan

† E-mail: obana.tetsuhiro@LHD.nifs.ac.jp
形状を簡略化した計算モデルを用いて、数值計算により評 価を行った。

本論文では、LHD サブクール冷却システムでの流動冷却 試験とコイル通電試験の結果、及び数值計算によるへリカ ルコイル巻線部の温度評価について記す。

\section{LHD サブクール泠却システム}

\section{1 冷却流路}

浸漬冷却型であるへリカルコイルの冷却流路図を、Fig. 1 に示す。流れの始点となる液体へリウム貯槽から、温度 4.4 $\mathrm{K}$ の飽和ヘリウムを供給する。次に、その飽和へリウムを 2 段の低温排気圧縮機と熱交換器を備えたサブクールクラ イオスタットによって、圧力一定の状態で、 $4.4 \mathrm{~K}$ (飽和温 度）から温度を低下させ、サブクール液体へリウムを生成 する。その後、サブクール液体ヘリウムは 2 系統の流路に 分岐され、入口ヘッダーを経由し、2 つのヘリカルコイル (HC コイル $1 、 \mathrm{HC}$ コイル 2) へ 10 箇所のコイル入口（最 下部）から供給される。

更に、コイル入口から出口（最上部）にかけて、流路が コイル内周側と外周側に分岐するため、コイル部分では、 20 の並列流路を有する。各流路長は、それぞれ $3.8 \mathrm{~m}$ (内 


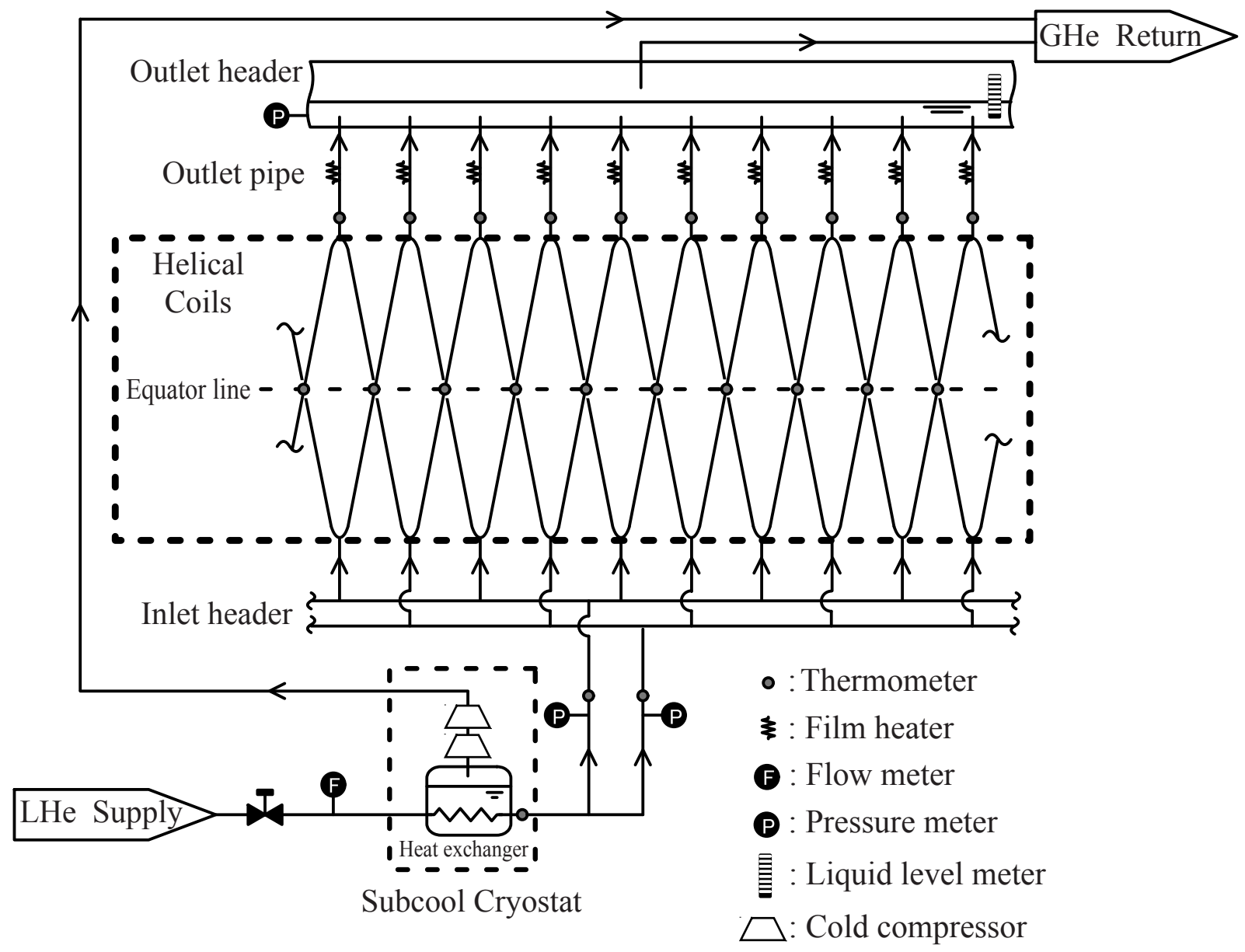

Fig. 1 Flow diagram of the LHD subcooling system.

周側）と $4.1 \mathrm{~m}$ (外周側) である。ヘリカルコイルを冷却 し終えて、コイル部分から出てきたサブクール液体へリウ ムは、10 箇所の各出口配管に設置されたフィルムヒータに よる加熱によって、飽和ヘリウムに戻されて、出ロヘッダ 一に回収される。入口ヘッダーと出ロヘッダーの間には高 低差があり、出口ヘッダーは入ロヘッダーよりも約 $4 \mathrm{~m}$ 高 い位置に設置されている。

LHD サブクール冷却システムの定格運転時における供 給流量は $50 \mathrm{~g} / \mathrm{s}$ であり、2つのヘリカルコイルにはそれぞ れ $25 \mathrm{~g} / \mathrm{s}$ の泠媒が供給される。Fig. 1 に示すように、コイ ル入口の流路はそれぞれ 5 箇所あるので、1 つの流路当た りの流量は $5 \mathrm{~g} / \mathrm{s}$ であり、コイル出口でも同様の流量とな る。また、コイル部分には 20 の並列流路があり、1つの流 路当たりの供給流量は、 $2.5 \mathrm{~g} / \mathrm{s}$ である。その際、入口へッ ダーと出口ヘッダーの圧力は、それぞれ約 $120 \mathrm{kPa}$ と約 110 $\mathrm{kPa}$ である。

2 つのヘリカルコイル容器内に含まれるサブクール液体 ヘリウムの容積は $2 \mathrm{~m}^{3}$ であり、液体ヘリウム貯槽から $2 つ$ のコイルへの供給流量が $50 \mathrm{~g} / \mathrm{s}$ の場合、約 2 時間でコイル 容器内の冷媒が入れ替わる。

\section{2 流量制御}

LHD サブクール冷却システムでは、サブクールクライオ スタットから出口ヘッダーまでの並列流路において、圧力 損失を極力低減するために、全くバルブを設置していない。 そこで、ヘリカルコイルへの供給流量は、サブクールクラ イオスタット手前のバルブ及び 10 箇所の出口配管に取り 付けたフィルムヒータを用いて制御した。各フィルムヒー 夕は並列回路で接続され、10 箇所の出口配管へ均一に加熱 した。ヒータは、最大 $2000 \mathrm{~W}$ 程度まで加熱が可能である。 定格運転の際には、バルブの開度を固定し、フィルムヒ ータからの出力を出ロヘッダーの液面が一定に保つように PID 制御することで、供給冷媒の流量制御を行った。

\section{3 計測}

導体に絶縁処理が施されていないへリカルコイルでは、 電気絶縁の観点から、ヘリカルコイル巻線部に温度計測素 子を設置していない。しかし、Fig. 1 に示すように、Cernox 温度計がコイル入口配管に 2 箇所、コイル出口配管に 10 箇所、コイル容器外周側で且つプラズマ真空容器側の赤道 面上に 10 箇所、更にサブクールクライオスタット内の熱交 換器出口に 1 箇所取り付けている。コイル出口配管に取り 付けた温度計は、フィルムヒータの発熱の影響を極力受け 
ないように、ヒータから $1 \mathrm{~m}$ 程度離れた位置に設置した。

圧力計は、コイル入口配管に 2 箇所、出ロヘッダーに 1 箇所設置した。また、流量計は、バルブとサブクールクラ イオスタットの間に、1 箇所設置した。

\section{3. 流動冷却試験}

\section{1 試験内容}

ヘリカルコイルに、定格流量 $50 \mathrm{~g} / \mathrm{s}$ のサブクール液体へ リウムを供給した状態で、低温排気圧縮機の回転数を制御 することにより、サブクール液体へリウムの温度を変化さ せた。その際のサブクールクライオスタット内、ヘリカル コイル出入口、及びコイル容器の温度測定を行った。

また、サブクールクライオスタット内の温度を $3.0 \mathrm{~K} に$ 保持した状態で、ヘリカルコイルへの供給流量を定格 50 $\mathrm{g} / \mathrm{s}$ から減少させた際の各部分での温度を測定した。

\section{2 冷媒温度の変化によるサブクール泠却システムへ の影響}

\section{2.1 温度特性}

サブクールクライオスタット内の温度に対するヘリカル コイル出入口温度とコイル容器温度を Fig. 2 に示す。ただ し、コイル入口は 2 箇所、コイル出口とコイル容器はそれ ぞれ 10 箇所に取り付けた温度計の平均值で評価した。Fig. 2 より、各部分の温度はサブクールクライオスタット温度 に対して、線形な関係となった。サブクール液体へリウム は、コイル入口から出口まで流れる際に、外部からへリカ ルコイルへの熱侵入によって加熱される。その結果、単相 流であるサブクール液体へリウムは、流れる方向に沿って 温度勾配が生じるため、各部分での温度が Fig. 2 に示すよ うな関係になったと考えられる。

また、コイル出口の圧力である $110 \mathrm{kPa}$ の際、温度が 4.3 $\mathrm{K}$ 未満であれば、液体へリウムはサブクール状態である。 従って、コイル入口温度を $3.6 \mathrm{~K}$ 以下に保持することで、 コイル出口温度が $4.3 \mathrm{~K}$ 未満となり、LHD のサブクール冷 却運転が可能になる。

\subsection{2 つのヘリカルコイル系統の温度差}

Fig. 3 に、ヘリカルコイル 1 ( $\mathrm{HC} 1)$ 系統とヘリカルコイ ル 2（HC2）系統の各部分での温度差を示す。各系統のコ イル出口とコイル容器は、それぞれ 5 箇所の温度の平均值 を求め、温度差を評価した。温度差 $\Delta T$ は、(1)式から求 めた。

$$
\Delta T=T_{H C 1}-T_{H C 2}
$$

ここで、 $T_{H C 1}$ は $\mathrm{HC} 1$ 系統での温度、 $T_{H C 2}$ は $\mathrm{HC} 2$ 系統で の温度である。

Fig. 3 より、流路が 2 つに分岐したコイル入口での両系 統の温度差は非常に小さく、コイル出口とコイル容器での 温度差は、 $0.05 \mathrm{~K}$ 程度である。この温度差は、コイル入口 配管の分岐部で起こる流量比の僅かな違い、及び外部から

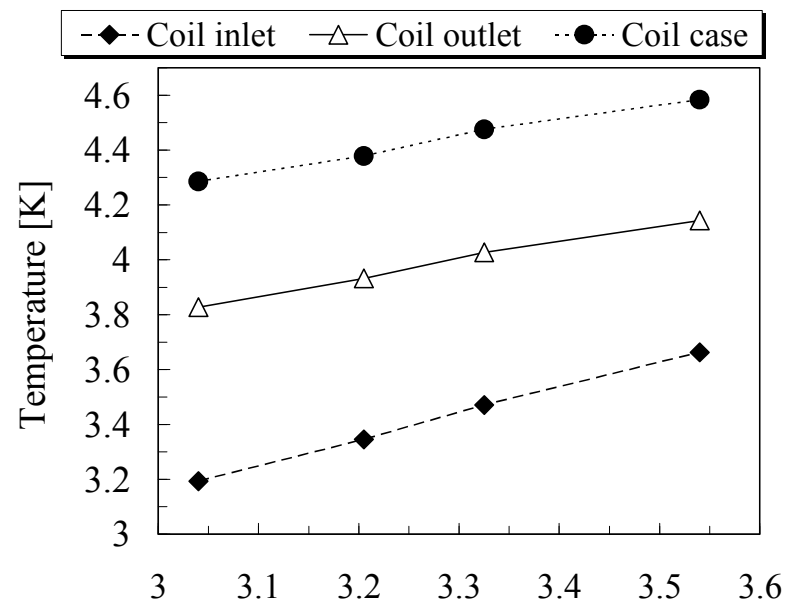

Temperature in the subcool cryostat $[\mathrm{K}]$

Fig. 2 Inlet, outlet and coil case temperatures for each temperature in the subcool cryostat at the mass flow rate of 50 g/s.

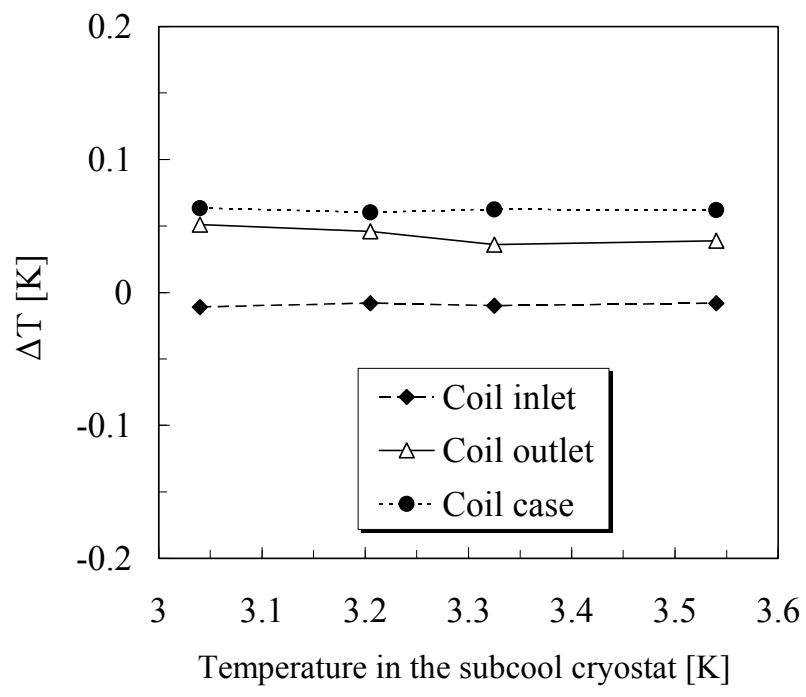

Fig. 3 Temperature differences between $\mathrm{H} 1$ and $\mathrm{H} 2$ at the inlet, outlet, and coil case for each temperature in the subcool cryostat.

の熱侵入量の違いに因るものだと考えられる。

両系統において、僅かな温度差が生じたものの、制御バ ルブを設置していない全長約 $4 \mathrm{~m}$ で最大 20 の並列流路に、 ほぼ均等に流量を供給することができた。その結果、サブ クール冷却システムにおいて、2 つのヘリカルコイルをほ ぼ均一に冷却することが可能であると考えられる。

\section{3 冷媒流量の変化によるサブクール冷却システムへ の影響}

\section{3.1 供給流量の減少}

本実験では、サブクールクライオスタット温度を $3.0 \mathrm{~K}$ に保持した状態で、供給流量を $50 \mathrm{~g} / \mathrm{s}$ から $25 \mathrm{~g} / \mathrm{s}$ まで減少 させた。その際の各部分の温度変化を Fig. 4 に示す。コイ 
ル出ロとコイル容器の温度は、各系統にそれぞれ 5 箇所取 り付けた温度計の平均值である。

供給流量を $25 \mathrm{~g} / \mathrm{s}$ 程度まで低下させた際、コイル出入口 において、急な温度変化が発生した。コイル出口では、温 度が飽和温度まで上昇し、またコイル入口では、H1 系統と H2 系統において、温度が交互に入れ替わった。従って、供 給流量を $25 \mathrm{~g} / \mathrm{s}$ 程度まで低下させた場合、サブクール冷却 システム内が不安定な状態に至ることが分かった。

その後、供給流量を $25 \mathrm{~g} / \mathrm{s}$ 程度で保持した場合には、す でに飽和温度に達した $\mathrm{H} 2$ 出口を除いて、各部分で温度が 上昇し続けた。最終的に、H1 入口と $\mathrm{H} 2$ 入口では、それぞ れ $3.95 \mathrm{~K}$ と $4.4 \mathrm{~K}$ に達した。また、H1 出口と $\mathrm{H} 2$ 出口では、 $4.3 \mathrm{~K}$ と $4.35 \mathrm{~K}$ に達した。コイル入口における約 $0.5 \mathrm{~K}$ の温 度差は、コイル入口配管の分岐部で、大きな流量比の不均 一が発生したことに因るものだと考えられる。結果として、 $\mathrm{H} 2$ 系統には、サブクール液体ヘリウムが供給されていない

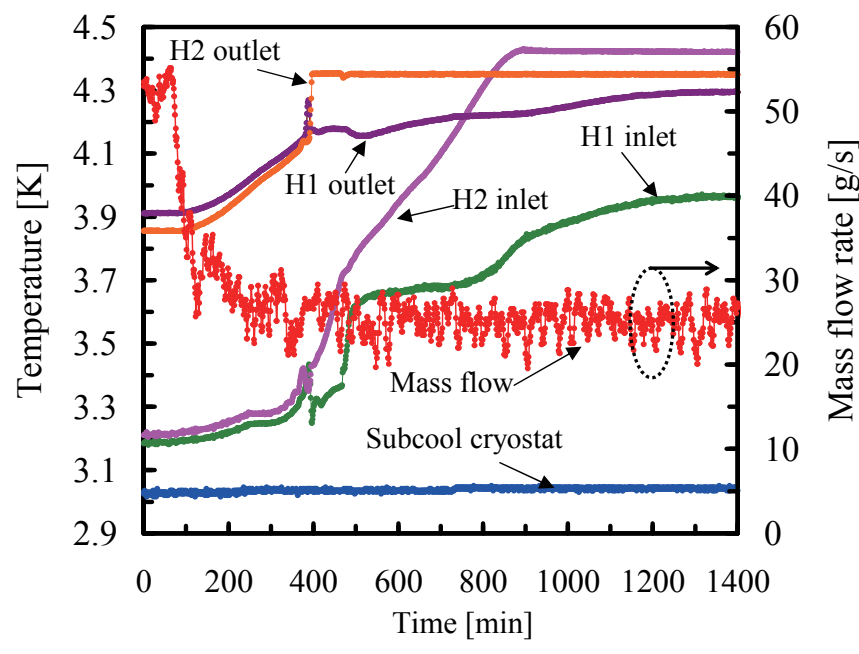

Fig. 4 Temperature profiles at each position in the LHD subcooling system when the mass flow rate was decreased while maintaining the temperature in the subcool cryostat.

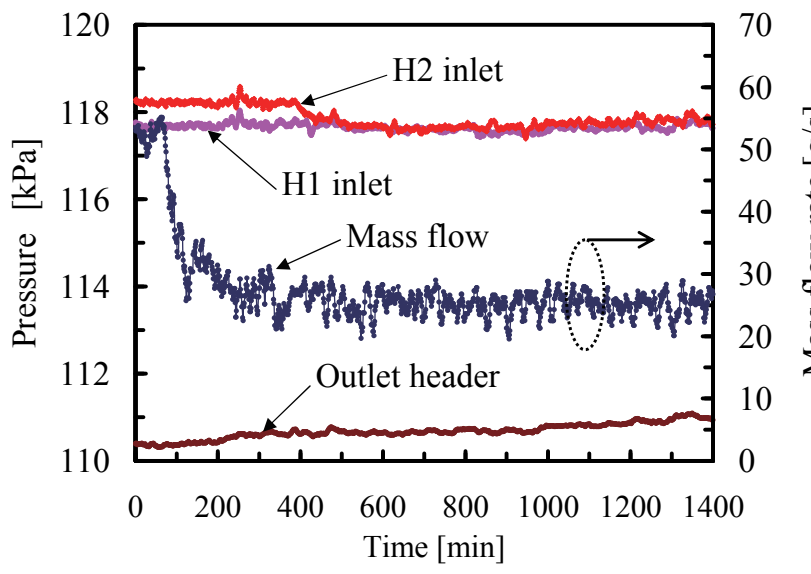

Fig. 5 Pressure profiles at the helical coil inlet and outlet.
と推測される。

また、H2 系統では、コイル入口温度がコイル出口温度よ りも約 $0.1 \mathrm{~K}$ 高い。この温度差は、高低差のあるコイル出 入口での圧力差が原因であると考えられる。Fig. 5 に、コ イル出入口での圧力を示す。コイル出入口での圧力差 $7 \mathrm{kPa}$ は、主に、飽和ヘリウムで満たされた $\mathrm{H} 2$ 系統での水頭圧 に因るものだと考えられる。高低差 $4 \mathrm{~m}$ のコイル出入口で の水頭圧は、(2)式により、 $5 \mathrm{kPa}$ である。残りの圧力差は、 液化/冷凍機からの影響であると考えられる。

$$
\Delta p_{\text {head }}=\rho_{\text {LHe }} \cdot g \cdot H
$$

ただし、 $\rho_{L H e}$ は飽和へリウムの密度, $g$ は重力加速度, $H$ は コイル出入口の高低差である。

\section{3. 2 供給流量の減少・増加}

本実験では、サブクールクライオスタット温度を $3.0 \mathrm{~K}$ に保持した状態で、供給流量を $50 \mathrm{~g} / \mathrm{s}$ から $25 \mathrm{~g} / \mathrm{s}$ に減少さ せた後、25 g/s から $50 \mathrm{~g} / \mathrm{s}$ まで流量を戻した。Fig. 6 に示す ように、供給流量を減少させるにつれて、コイル出入口の 温度が上昇した。供給流量を $25 \mathrm{~g} / \mathrm{s}$ まで減少させた際には、 コイル出入口の温度が大きく変化した。特に、H2 系統のコ イル出口では、 $4.1 \mathrm{~K}$ から飽和温度に急に上昇した。そこで、 コイル出口での温度差を抑えるために、供給流量を増加し た。その際に、コイル出入口で急激な温度変化が発生した。 供給流量を $30 \mathrm{~g} / \mathrm{s}$ まで増加した際、H2 コイル入口温度が、 短時間で、 $3.8 \mathrm{~K}$ 一増加し、 $3.2 \mathrm{~K}$ まで減少した。また同時 に、H2 コイル出口は、飽和温度から $4.2 \mathrm{~K}$ まで減少し、H1 コイル出口は、 $4.1 \mathrm{~K}$ から飽和温度まで増加した。

更に、供給流量を $50 \mathrm{~g} / \mathrm{s}$ まで戻す際に、H1 入口の温度は、 $3.8 \mathrm{~K}$ まで急激に増加し、その後 $3.2 \mathrm{~K}$ まで減少した。 $\mathrm{H} 1$

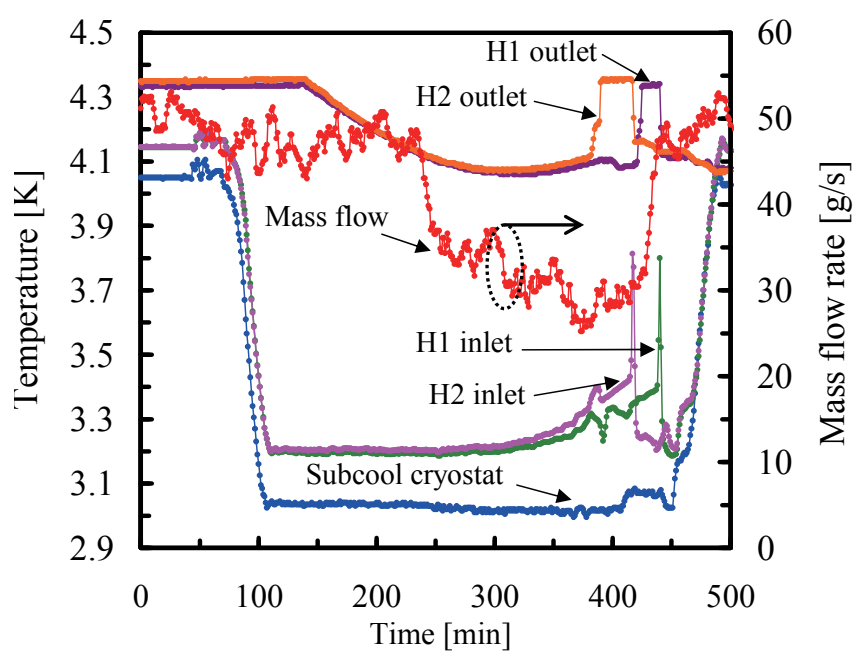

Fig. 6 Temperature profiles at each position in the LHD subcooling system when the mass flow rate was decreased and increased while maintaining the temperature in the subcool cryostat. 
コイル出口では、飽和温度から $4.1 \mathrm{~K}$ まで降下した。本実 験結果より、供給流量が定格運転である $50 \mathrm{~g} / \mathrm{s}$ から $25 \mathrm{~g} / \mathrm{s}$ 程度まで低下寸る際、及び $25 \mathrm{~g} / \mathrm{s}$ 程度から定格運転の状態 に回復する過程において、不安定現象がサブクール冷却シ ステムで発生することが分かった。

供給流量が $30 \mathrm{~g} / \mathrm{s}$ 以上の場合、Fig.1 に示すように、コイ ル入口から出口に向かって冷媒が供給される。しかし、供 給流量が $25 \mathrm{~g} / \mathrm{s}$ 程度まで減少した際、出ロヘッダーで回収 した飽和へリウムが一時的に H2 コイルへ流れ込んだと考 えられる。また、供給流量を $25 \mathrm{~g} / \mathrm{s}$ から増加させた際には、 出口ヘッダーから飽和ヘリウムが $\mathrm{H} 2$ コイルではなく $\mathrm{H} 1$ コイルへ流れ込んだと考えられる。すなわち、サブクール 冷却システム内で、冷媒の不安定な流れが起きたと推測さ れる。その原因は、液化/冷凍機からの供給圧とコイル出入 ロでの水頭圧が関係していると考えられる。

\section{4. ヘリカルコイル通電試験}

\section{1 試験方法}

ヘリカルコイルの通電によるサブクール冷却システム の影響を検証した。コイル通電の際には、ヘリカルコイル に流量 $50 \mathrm{~g} / \mathrm{s}$ のサブクール液体ヘリウムを供給した状態 で、サブクールクライオスタット内温度 $3.0 \mathrm{~K}$ 、コイル入口 温度 $3.2 \mathrm{~K}$ に保持した。供給流量の制御は、出口ヘッダー の液面計に連動したコイル出口のヒータによって行い、サ ブクールクライオスタット手前の制御バルブの開度は固定 した。

コイル通電試験では、励磁速度 $3.5 \mathrm{~A} / \mathrm{s}$ で $11.3 \mathrm{kA}$ (トロ イダル磁場 $2.75 \mathrm{~T}$ ) までの励磁、及び励磁速度 $7.0 \mathrm{~A} / \mathrm{s}$ で 11.0 kA（トロイダル磁場 $2.68 \mathrm{~T}$ ）までの励磁を行った。通電試 験において、ヘリカルコイルを構成する 3 ブロック（H-I、 $\mathrm{H}-\mathrm{M} 、 \mathrm{H}-\mathrm{O})$ への通電電流值は、ほぼ同じである。へリカ ルコイルの詳細は、次章に記す。

\section{2 試験結果と考察}

\section{2.1 励磁速度 $3.5 \mathrm{~A} / \mathrm{s}$ 、通電電流値 $11.3 \mathrm{kA}$ の場合}

Fig. 7 に、通電試験時の電流波形、両冷却系統 (H1 と $\mathrm{H} 2)$ のコイル出入口温度とコイル容器温度を示す。コイル入口 温度は、通電による影響を受けることなく、3.2 K を保持す ることができた。しかしながら、コイル出口とコイル容器 では、励磁に伴う交流損失により、温度上昇が起きた。コ イル出口とコイル容器で、それぞれ約 $0.1 \mathrm{~K}$ 上昇した。ま た、コイル容器温度は、交流損失の影響を受け易いため、 励磁開始と同時に温度変化が起きた。一方、コイル出口は、 冷媒の影響を大きく受けるため、コイル容器に比べて温度 変化が遅い。

本通電試験でのコイル巻線部における交流損失を、(3) 式を用いて、コイル出口の温度に対するエンタルピー変化 から算出した。

$$
Q=\int\left(H_{\text {outlet }}-H_{\text {initial }}\right) \cdot \dot{m} d t
$$

ここで、 $Q$ は交流損失、 $H_{\text {outet }}$ はコイル出口温度でのエンタ ルピー、 $H_{\text {initial }}$ は励磁開始前のコイル出口温度に対するエン タルピー、 $\dot{m}$ は質量流量、 $d t$ は時間である。その結果、交 流損失は約 $290 \mathrm{~kJ}$ となった。

コイルを $11.3 \mathrm{kA}$ まで励磁した後に、コイル出口温度は 最高温度に到達し、その後温度が低下し始めた。コイル出 口の温度減衰時定数は、約 $140 \mathrm{~min}$ であった。

\section{2.2 励磁速度 $7.0 \mathrm{~A} / \mathrm{s}$ 、通電電流値 $11.0 \mathrm{kA}$ の場合}

Fig. 8 に、励磁速度 $7.0 \mathrm{~A} / \mathrm{s}$ で $11.0 \mathrm{kA}$ まで励磁した電流 波形及び温度測定結果を示す。励磁速度 $3.5 \mathrm{~A} / \mathrm{s}$ から $7.0 \mathrm{~A} / \mathrm{s}$ に増加させても、通電によるコイル入口温度への影響は見 られなかった。しかしながら、コイル出口及びコイル容器 では、励磁速度 $3.5 \mathrm{~A} / \mathrm{s}$ の場合に比べて、急激に温度が上昇 した。その際、コイル出口温度が約 $0.15 \mathrm{~K}$ 、コイル容器温 度が約 $0.2 \mathrm{~K}$ 上昇した。本コイル通電試験時のコイル出口 温度に対するエンタルピー変化から、(3)式を用いて求めた コイル巻線部における交流損失は約 $360 \mathrm{~kJ}$ であった。

本試験条件下でも、コイルを $11.0 \mathrm{kA}$ まで励磁した後に コイル出口温度は最高温度に到達し、温度減衰時定数は約 $140 \min$ となった。

\section{2.3 コイル励磁によるサブクール冷却システムへの 影響}

励磁速度 $3.5 \mathrm{~A} / \mathrm{s}$ で $11.3 \mathrm{kA}$ までの励磁、及び励磁速度 7.0 $\mathrm{A} / \mathrm{s}$ で $11.0 \mathrm{kA}$ までの励磁において、コイル出口温度とコイ ル容器温度の上昇は起きるが、安定してサブクール冷却シ ステムを運転することが可能である。しかしながら、励磁 速度 $3.5 \mathrm{~A} / \mathrm{s}$ で $11.25 \mathrm{kA}$ まで励磁した後、交流損失の影響 を軽減するために、励磁速度を $3.5 \mathrm{~A} / \mathrm{s}$ から $0.7 \mathrm{~A} / \mathrm{s}$ まで減

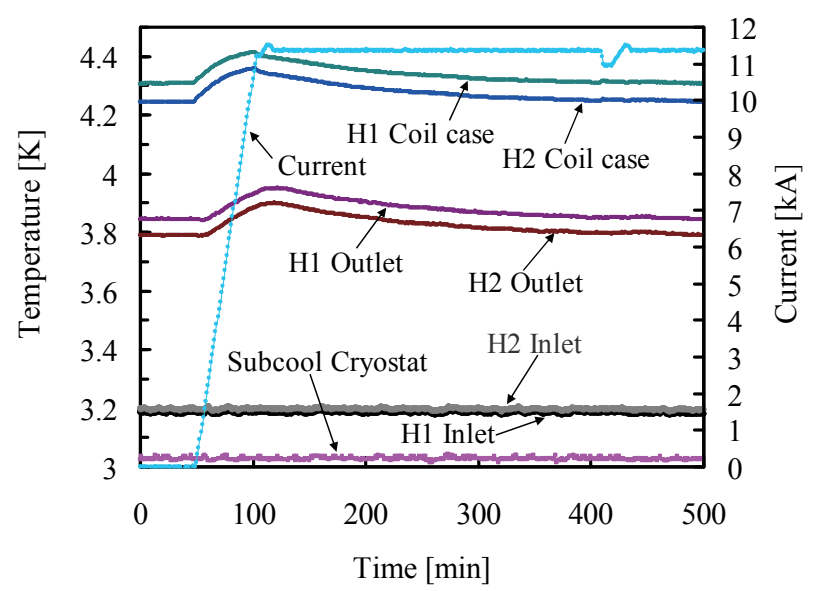

Fig. 7 Temperature profiles at each position in the LHD subcooling system under coil excitation up to $11.3 \mathrm{kA}$ with the ramp rate of $3.5 \mathrm{~A} / \mathrm{s}$. 


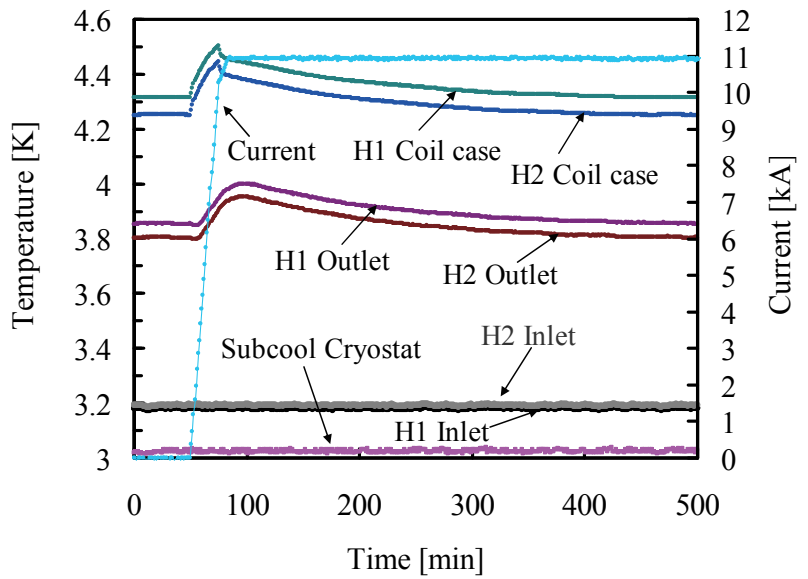

Fig. 8 Temperature profiles at each position in the LHD subcooling system under coil excitation up to $11.0 \mathrm{kA}$ with the ramp rate of $7.0 \mathrm{~A} / \mathrm{s}$.

少し、更に高磁場を目指した励磁を行ったところ、通電電 流值が 11.45 kA の際に H2 コイルの H-I ブロックで常伝導 伝播が発生した ${ }^{4)}$ 。そこで、現在は、コイル通電を行う際 に、コイル出口の温度減衰時定数を考慮して、11.0 kA まで 励磁した後、電流值を約 2 時間保持する。その後、コイル 出口が励磁開始前の温度にほぼ戻りつつあることを確認 し、励磁速度 $1.0 \mathrm{~A} / \mathrm{s}$ 程度で励磁を再開している。上記のコ イル励磁により、11.6 kA 程度までのコイル通電が可能にな った ${ }^{5)}$ 。

\section{5. ヘリカルコイル巻線部の温度評価}

電気絶縁の観点から、ヘリカルコイル巻線部には温度計 が設置されていないため、コイル巻線部の温度を実測する ことができない。そこで、数值計算により、コイル巻線部 温度の評価を行った。

\section{1 LHD ヘリカルコイルと冷却流路}

Fig. 9 に示すように、螺旋形状を有する 2 対の LHD へリ カルコイルは、高純度アルミニウムで安定化した $\mathrm{NbTi} / \mathrm{Cu}$ 複合超伝導導体を用いて冷却端安定化した浸漬冷却型コイ ルである。Table 1 に、ヘリカルコイルの詳細を示す ${ }^{6,7,8)}$ 。 ヘリカルコイル巻線部は、H-I、H-M、H-O の 3 つのブロッ クから構成され、Fig. 10 に示寸ように、超伝導導体間には、 コイル長手方向に沿って一定の間隔で GFRP スペーサーが 設置されている。そのため、Fig. 1 のように、コイル入口 配管から供給されたサブクール液体ヘリウムは、導体の四 隅と GFRP スペーサー間にできる僅かな空間、及びコイル 巻線部とコイル容器間にできる空間を流れる。その冷却流 路断面積は約 $2600 \mathrm{~mm}^{2}$ であり、超伝導導体の 11.5 個分に 相当する。

\section{2 計算モデルと境界条件}

外部からの熱侵入やコイル励磁に伴う発熱のような、へ
リカルコイル全体に対して、ほぼ均一に入熱がある場合は、 ヘリカルコイルの半ピッチ分で、コイル巻線部温度の評価 をすることが可能である。そこで、本計算では、へリカル コイル形状を簡略化した準 1 次元モデルを用いて、コイル 入口から出口までのヘリカルコイルの半ピッチ分 $(3.92 \mathrm{~m})$ におけるコイル巻線部温度を評価した。ヘリカルコイルの 半ピッチ分は、Fig. 1 に示すコイル部分における並列流路 の 1 つの流路にあたる。

Fig. 11 に、計算モデルの概略図と計算時の境界条件を示 す。本計算モデルは、コイル巻線部、コイル容器、サブク 一ル液体ヘリウム流路の 3 つの部分から成り、実機のへリ カルコイルと同じ体積(熱容量) とした。ヘリカルコイルを モデル化する際、コイル巻線部は、超伝導導体、GFRP ス ペーサー、及び超伝導導体と GFRP スペーサー間に含まれ るサブクール液体ヘリウムから構成される部分とした。ま た、計算モデルのサブクール液体ヘリウム流路は、Fig. 10

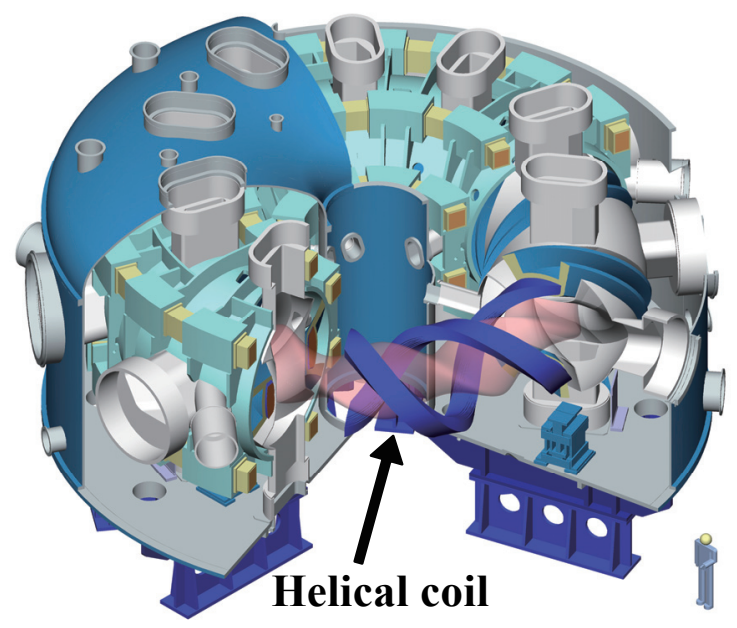

Fig. 9 Schematic view of the LHD helical coils confining plasma.

Table 1 Main specifications of the LHD helical coils.

\begin{tabular}{|l|l|}
\hline Major radius & $3.9 \mathrm{~m}$ \\
\hline Minor radius & $0.975 \mathrm{~m}$ \\
\hline Toroidal pitch number & 10 \\
\hline Number of coil turns & $450(150 \times 3$ blocks $)$ \\
\hline Conductor size & $12.5 \mathrm{~mm} \times 18.0 \mathrm{~mm}$ \\
\hline Coil weight & $75.2 \mathrm{t} /$ coil \\
\hline Cooling method & Pool-boiling of liquid He \\
\hline Material of coil case & SUS316 \\
\hline Wetted surface fraction & $0.417-0.692$ \\
\hline Central toroidal field & $3.0 \mathrm{~T}$ \\
\hline Maximum field & $6.9 \mathrm{~T}$ \\
\hline Magnetic stored energy & $0.95 \mathrm{GJ}$ \\
\hline Nominal current & $13.0 \mathrm{kA}$ \\
\hline
\end{tabular}




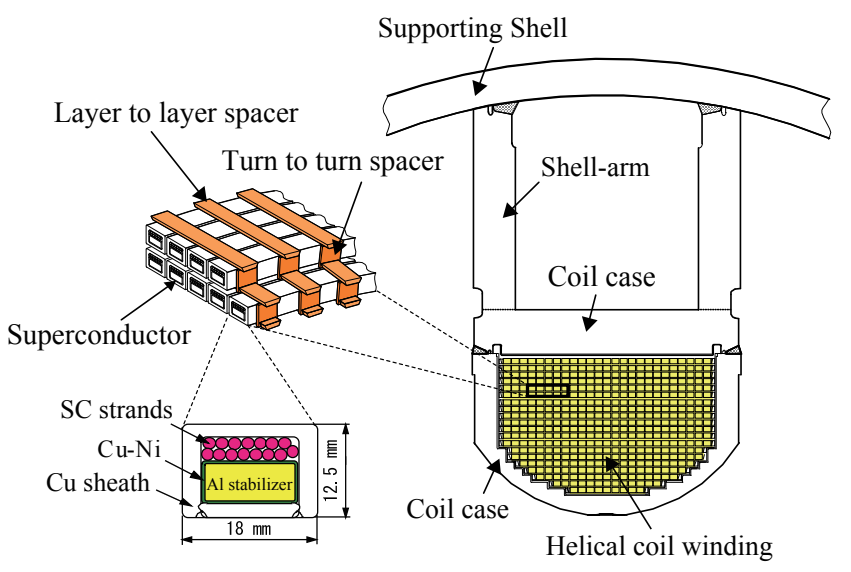

Fig. 10 Schematic view of a cross-section of the helical coil, a piece of the coil winding and a cross-section of the superconductor.

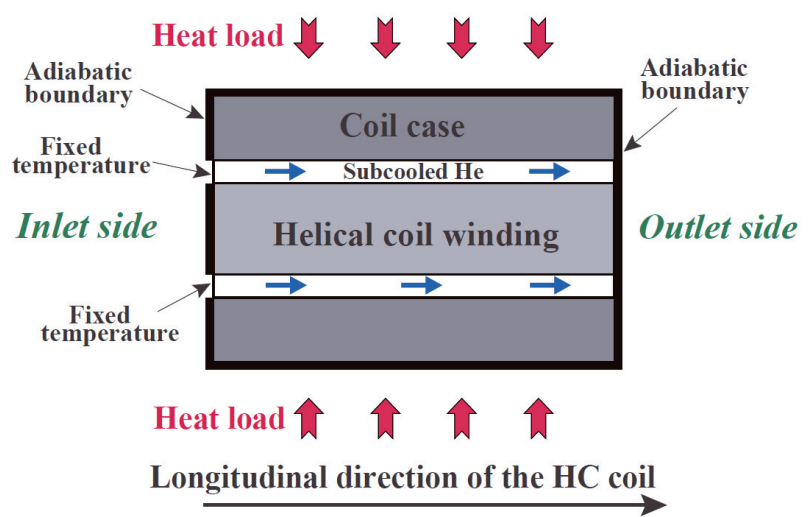

Fig. 11 Schematic view of the numerical calculation model simplifying the helical coil.

に示すコイル巻線部とコイル容器の間にできる流路とし た。

境界条件に関しては、Fig. 11 に示すように、サブクール 液体へリウム流路の入口側温度を固定し、コイル容器側面 に対して入熱を与えた。その入熱量は、ヘリカルコイル上 部に位置する出口ヘッダーの液面変化から評価した熱侵入 量 $90 \mathrm{~W}$ とした。その他のモデル外周部は、断熱条件とし た。また、初期条件に関しては、モデル全体の温度をサブ クール液体ヘリウム流路の入口側温度と同じ值にした。

\section{3 基礎方程式}

計算モデルのコイル巻線部とコイル容器では、1 次元熱 伝導方程式である(4)式を用い、サブクール液体ヘリウム流 路では、供給流量を考慮した(5)式を用いた。また、コイル 巻線部とサブクール液体ヘリウム流路の境界、及びコイル 容器とサブクール液体へリウム流路の境界では、界面での 熱抵抗を考慮して、(6)式を用いた。サブクール液体へリウ ムは定格運転である流量 $50 \mathrm{~g} / \mathrm{s}$ でヘリカルコイルに供給さ
れる場合、コイル入口から出口までの $4 \mathrm{~m}$ 程度の距離を約 2 時間かけて流れる。上記のような、低速で供給されるサ ブクール夜体ヘリウム中では、外部からの定常熱侵入によ る影響で、自然対流が発生していると考えられる。そこで、 界面での熱伝達率には、液体へリウムの非沸騰自然対流領 域における関係式である(7)式を用いた ${ }^{9,10)}$

$$
\begin{aligned}
& \rho \cdot c_{p} \cdot \frac{\partial T}{\partial t}=\frac{\partial}{\partial x}\left(\lambda \frac{\partial T}{\partial x}\right)+Q_{\text {thick }} \\
& \rho \cdot c_{p} \cdot \frac{\partial T}{\partial t}=\frac{\partial}{\partial x}\left(\lambda \frac{\partial T}{\partial x}\right)+Q_{\text {thick }}-\rho \cdot c_{p} \cdot u \cdot \frac{\partial T}{\partial x} \\
& q=h \cdot \Delta T \\
& h=c \cdot \Delta T^{1 / 3}
\end{aligned}
$$

ただし、 $\rho$ は密度、 $c_{p}$ は比熱、 $T$ は温度、 $t$ は時間、 $x$ は長手 方向の距離、 $\lambda$ は熱伝導率、 $Q_{\text {thick }}$ は幅方向の移動熱量、 $u$ は流速、 $q$ は界面での熱流束、 $\Delta T$ は温度差、 $h$ は熱伝達 率、 $c$ は定数を示す。

数值計算を行う際は、(4)式と(5)式を差分化し、陽解法を用

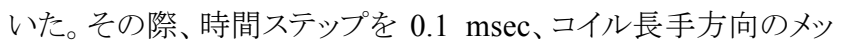
シュサイズを $0.784 \mathrm{~m}$ とした。また、差分化した(6)式を時間ステ ップごとに解き、各界面での熱流束を求めた。

計算モデルのコイル巻線部では、単位体積あたりの熱容 量に、超伝導導体、GFRP スペーサー、及びサブクール液 体ヘリウムを合成した值を用いた。その際、コイル巻線部 とサブクール液体ヘリウムの導体露出率 $50 \%$ とし、ヘリ カルコイル断面での各断面積比を考慮した。Fig. 12 に、へ リカルコイル巻線部の単位体積あたりの熱容量を示す。ま た、コイル巻線部の熱伝導率には、超伝導導体を構成する $\mathrm{NbTi} / \mathrm{Cu}$ 素線、 $\mathrm{Al}$ 安定化材、 $\mathrm{Cu}-\mathrm{Ni} 、 \mathrm{Cu}$ シース、 $\mathrm{Sn} 60 \mathrm{~Pb}$ 半 田の断面積比を考慮して合成した值を用いた。Fig. 13 に、 コイル巻線部、サブクール液体ヘリウム流路、及びコイル

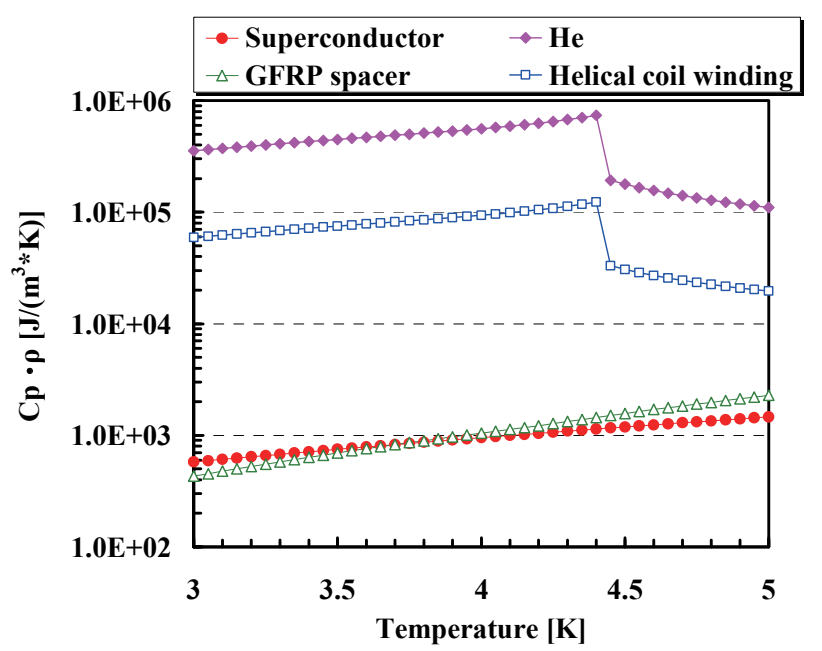

Fig. 12 Heat capacity per unit volume of the helical coil winding. 


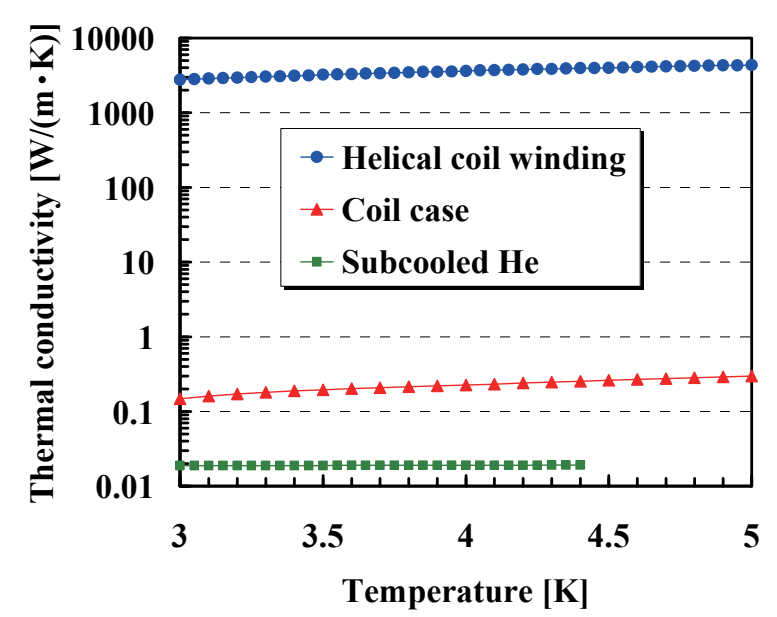

Fig. 13 Thermal conductivity of the numerical model.

容器の熱伝導率を示す。

\section{4 計算結果}

\section{4.1 定常熱侵入時におけるヘリカルコイル温度}

サブクール液体ヘリウムで浸漬冷却されたヘリカルコイ ル巻線部への定常熱侵入による影響を検証した。計算を行 う際、サブクール液体ヘリウム供給時におけるへリカルコ イルへの定常熱侵入量を $90 \mathrm{~W}$ とした。Fig. 14 に、各コイ ル入口温度に対するコイル容器（赤道部）温度の実験結果 と計算結果を示す。また、Fig. 15 に、各コイル入口温度に 対するコイル出口温度の実験結果と計算結果を示す。本結 果より、ヘリカルコイルを簡略化した準 1 次元計算モデル を使用した際、定常熱侵入時におけるコイル容器及びコイ ル出口温度の変化をほぼ再現することができた。

\subsection{2 コイル励磁時におけるヘリカルコイル温度}

ヘリカルコイルの励磁時に生じるコイル巻線部の温度変

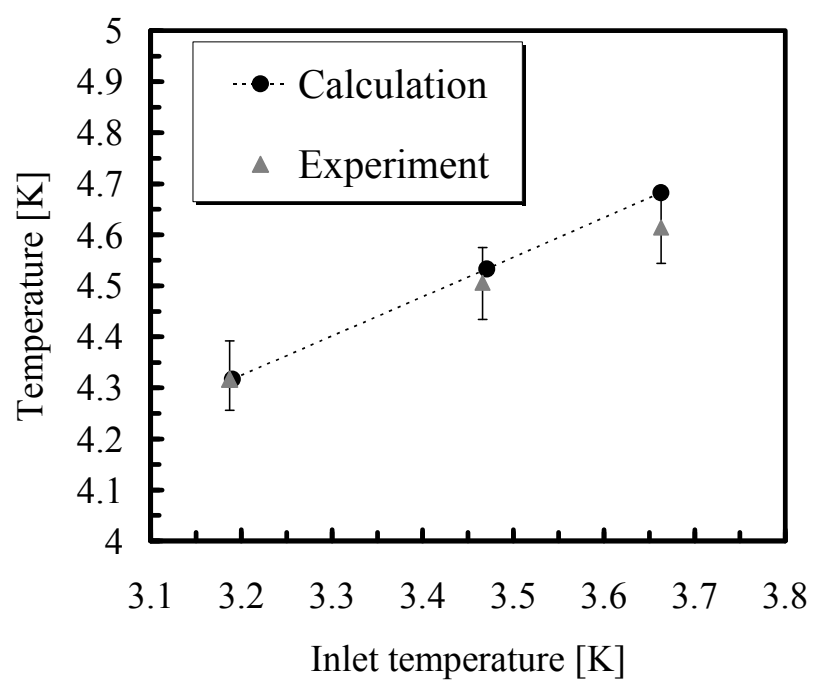

Fig. 14 Experiment and calculation results of the coil case temperatures at the equatorial plane.

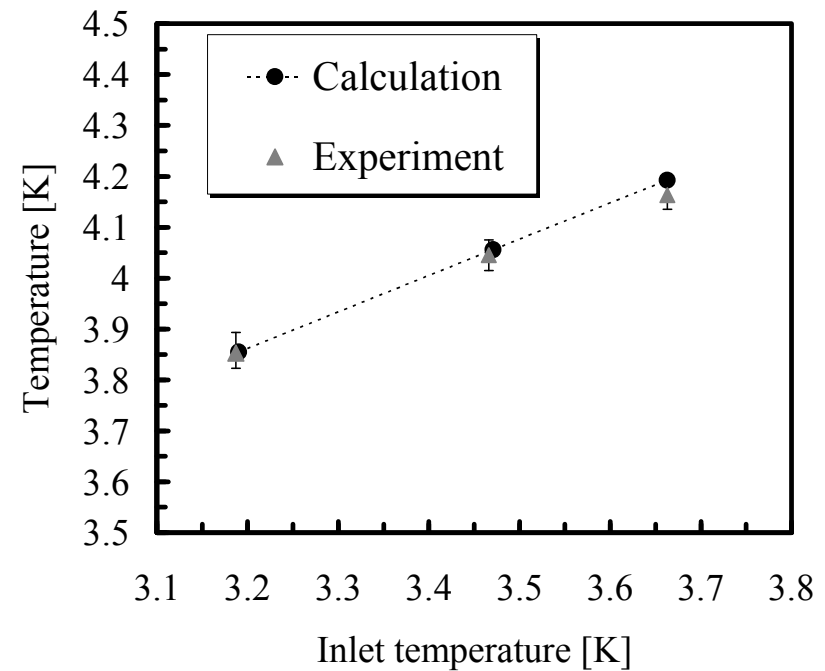

Fig. 15 Experiment and calculation results of the coil outlet temperatures.

化を数值計算により検証した。数值計算を行う際には、実 験結果から得られた交流損失による発熱を考慮するため、

(4)式に、発熱の項 $Q_{A C}\left[\mathrm{~W} / \mathrm{m}^{3}\right]$ を新たに加えた(8)式を、コ イル巻線部とコイル容器に用いた。

$$
\rho \cdot c_{p} \cdot \frac{\partial T}{\partial t}=\frac{\partial}{\partial x}\left(\lambda \frac{\partial T}{\partial x}\right)+Q_{\text {thick }}+Q_{A C}
$$

Fig. 16 に、励磁速度 $3.5 \mathrm{~A} / \mathrm{s}$ で $11.3 \mathrm{kA}$ まで励磁した際の ヘリカルコイル各部分の温度に対する実験結果と計算結果 を示す。時間 $0 \mathrm{~min}$ から $50 \mathrm{~min}$ までは、定常熱侵入 $(90 \mathrm{~W})$ におけるへリカルコイルの温度を示す。コイル励磁は 50

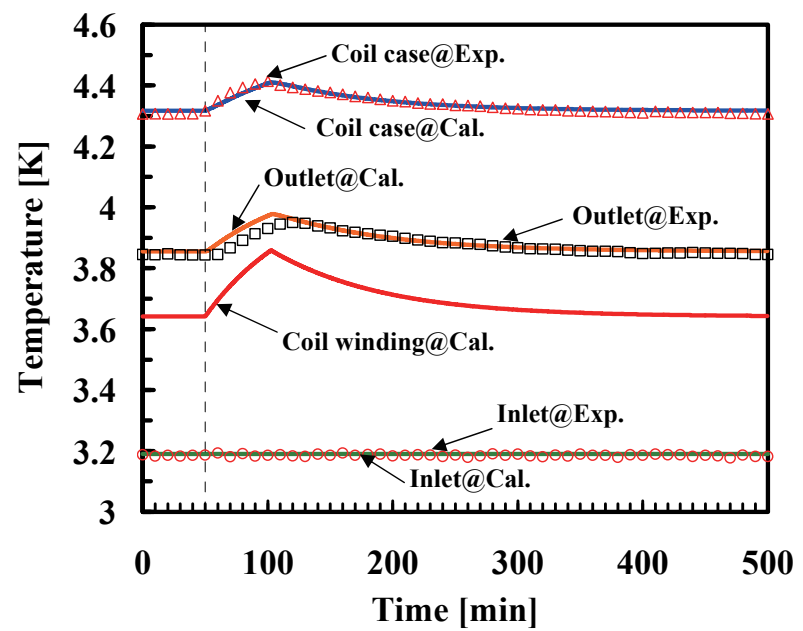

Fig. 16 Temperature profiles in the experiment and calculation under coil excitation up to $11.3 \mathrm{kA}$ with the ramp rate of $3.5 \mathrm{~A} / \mathrm{s}$. Dots and lines show experiment results and calculation results, respectively. 


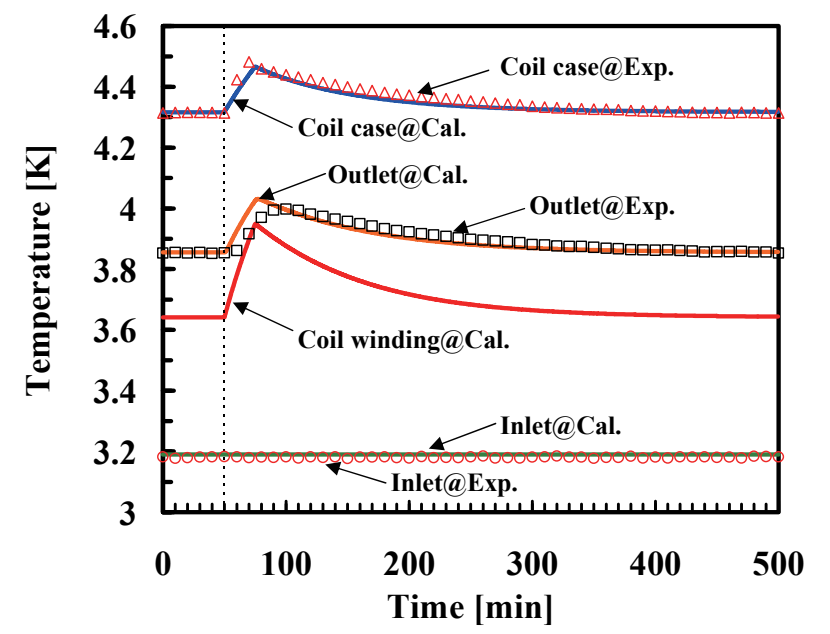

Fig. 17 Temperature profiles in the experiment and calculation under coil excitation up to $11.0 \mathrm{kA}$ with the ramp rate of $7.0 \mathrm{~A} / \mathrm{s}$. Dots and lines show experiment results and calculation results, respectively.

$\min$ から開始した。コイル容器とコイル出入口において、 コイル励磁時における温度変化を数值計算により、ほぼ再 現することができた。その結果により、コイル巻線部の温 度はコイルの励磁によって、コイル出口温度に近づくこと が分かった。

励磁速度 $7.0 \mathrm{~A} / \mathrm{s}$ で $11.0 \mathrm{kA}$ までの励磁時における、ヘリ カルコイル各部分の温度に対する実験結果と計算結果を Fig. 17 に示す。時間 $0 \mathrm{~min}$ から $50 \mathrm{~min}$ までは、定常熱侵入 $(90 \mathrm{~W})$ におけるへリカルコイルの温度であり、50 min か らコイル励磁を開始した。コイル励磁直後のコイル出口温 度において、計算結果と実験結果で若干の温度差が見られ るが、全体的には、数值計算により、コイル励磁時におけ る温度変化をほぼ再現することができた。その際、コイル 巻線部の温度は、励磁速度 $3.5 \mathrm{~A} / \mathrm{s}$ に比べると、更にコイル 出口温度に近づいた。従って、励磁速度の増加に伴って、 コイル巻線部の温度上昇が大きくなることが分かった。

\section{6. まとめ}

LHD サブクール冷却システムの特性を理解するために、 流動冷却試験、コイル通電試験、及び数值計算によるへリ カルコイル巻線部の温度評価を行った。その結果、全長約 $4 \mathrm{~m}$ で最大 20 の並列冷却流路を有するへリカルコイルを、 サブクール液体ヘリウムで均一に冷却できることを確認し た。また、サブクール冷却システムを安定に運転するため には、サブクールクライオスタット温度が $3.0 \mathrm{~K}$ の場合、 ヘリカルコイルヘの供給流量を $30 \mathrm{~g} / \mathrm{s}$ 以上に保持しなけれ ばならないことが分かった。

励磁速度 $3.5 \mathrm{~A} / \mathrm{s}$ で電流值 $11.3 \mathrm{kA}$ までのコイル通電、及 び励磁速度 $7.0 \mathrm{~A} / \mathrm{s}$ で電流值 $11.0 \mathrm{kA}$ までのコイル通電に伴 う交流損失により、コイル出口とコイル容器で $0.2 \mathrm{~K}$ 程度
の温度上昇が発生したが、コイル入口温度は一定に制御す ることができた。

ヘリカルコイル形状を簡略化した計算モデルを用いて数 值計算を行った結果、コイルへの定常熱侵入及び交流損失 によるコイル出口温度とコイル容器温度の変化をほぼ再現 することができた。ヘリカルコイル励磁の際には、コイル 巻線部温度がコイル出口温度に近づくことが分かった。ま た、コイル巻線部の温度上昇は、コイル励磁速度の増加に 伴って大きくなることが分かった。

\section{参 考 文 献}

1) S. Imagawa, et al.: "Achievement of high availability in long-term operation and upgrading plan of the LHD superconducting system," Nuclear Fusion 47 (2007) 353-360

2) S. Hamaguchi, et al.: "Performance of upgraded cooling system for LHD helical coils," Advances in Cryogenics 53B (2008) 1724-1730

3) T. Obana, et al.: "Performance tests of the subcooling system for the LHD helical coils," IEEE Trans. Appl. Supercond. 18 (2008) $1475-1478$

4) S. Imagawa, et al.: "Results of the excitation test of the LHD helical coils cooled by subcooled helium," IEEE Trans. Appl. Supercond. 18 (2008) 455-458

5) S. Imagawa, et al.: "Results of lowering temperatures of the LHD helical coils subcooled system," Abstracts of CSJ Conference $\mathbf{8 0}$ (2009) 33

今川信作ら：「LHD ヘリカルコイルの過冷却（サブクール） 改造の成果」第 80 回 2009 年春季低温工学・超電導学会講演 概要集 (2009) 33

6) T. Mito, et al.: "Applied superconductivity and cryogenic research activities in NIFS," Fusion Eng. Design 81 (2006) 2389-2400

7) S. Imagawa, et al.: "Design and construction of helical coils for LHD," Fusion Eng. Design 41 (1998) 253-258

8) S. Imagawa: "Development and fabrication of superconducting helical coils for LHD - Development and fabrication of helical coils for LHD -," TEION KOGAKU 32 (1997) 553-561 (in Japanese)

今川信作:「超伝導へリカルコイルの開発と製作一へリカルコ イルーの開発と製作」低温工学 32 (1997) 553-561

9) S. Sato and H. Ogata: "Review of boiling heat transfer to helium-part 1,” TEION KOGAKU 12 (1977) 2-18 (in Japanese) 佐藤新太郎、尾形久直:「へリウムの沸騰熱伝達研究の展望 (そ の 1 )」低温工学 12 (1977) 2-18

10) A.P. Dorey: "Heat transfer at low temperatures," Cryogenics 5 (1965) 146-151

尾 花 哲 浩 昭和 52 年 12 月 17 日生。平成 13 年東京理科 大学理工学部物理学科卒業。平成 15 年東京工業大学大学院総合理 工学研究科修士課程修了。平成 18 年総合研究大学院大学高エネル ギー加速器科学研究科博士後期課程修了。同年 4 月より核融合科 学研究所助手。現在、同研究所助教。主に加速器及び核融合用超 伝導磁石の研究開発に従事。低温工学協会、日本磁気学会会員。 博士 (工学)。 
濱口 真 司 昭和 45 年 10 月 12 日生。平成 5 年東京工業大 学理学部応用物理学科卒業。平成 10 年同大学大学院総合理工学研 究科創造エネルギー専攻博士後期課程修了。同年 4 月核融合科学 研究所 $\mathrm{COE}$ 着任。同年 7 月同研究所大型ヘリカル研究部助手。現 在、同助教。主に超伝導磁石の冷却に関寸る研究に従事。低温工 学協会、プラズマ・核融合学会会員。博士 (工学)。

柳長 門 1962 年 12 月 24 日生。1989 年 12 月京都大学大 学院工学研究科博士後期課程中退。同 12 月、核融合科学研究所大 型ヘリカル研究部助手。2000 年より同助教授（現在は准教授）。 主に、大型ヘリカル装置（LHD）のヘリカルコイル用超伝導導体 の開発および特性研究や、核融合エネルギー炉用の大電流容量 HTS 導体の開発研究に従事。また、ヘリオトロン磁場配位の最適 設計に取り組む。低温工学協会、日本物理学会、プラズマ・核融 合学会員。博士 (工学)。

三戸 利 行 昭和 30 年 12 月 21 日生。昭和 53 年九州大学工 学部電子工学科卒業。昭和 58 年同大学大学院工学研究科博士課程 修了。同年 4 月高エネルギー物理学研究所助手、昭和 63 年 8 月京 都大学ヘリオトロン核融合研究センター助教授、平成元年 5 月核 融合科学研究所・大型ヘリカル研究部・装置技術研究系助教授、 平成 10 年 12 月同研究所教授、平成 11 年 4 月総合研究大学院大学. 数物科学研究科核融合科学専攻・教授併任、平成 15 年 4 月核融合 科学研究所 - 大型ヘリカル研究部 - 装置技術研究系研究主幹、平 成 16 年 4 月大学共同利用機関法人・自然科学研究機構 ・核融合科 学研究所・大型ヘリカル研究部・炉システム・応用技術研究系研 究主幹、同教授、国立大学法人 - 総合研究大学院大学・物理科学
研究科・核融合科学専攻・教授併任、現在に至る。主として先進 超伝導導体の開発研究、大型超伝導・低温システムの最適化研究、 高温超伝導の核融合装置への応用研究に従事。低温工学協会、プ ラズマ核融合学会、電気学会会員。工学博士。

森 内 貞 智 昭和 42 年 8 月 22 日生。平成 10 年名古屋工業 大学工学部 II 部機械工学科卒業。平成 4 年 8 月核融合科学研究所 技術部装置技術課技官、平成 12 年 4 月同低温技術係長、現在に至 る。主に大型冷凍システムの運転・保守業務に従事。低温工学協 会会員。

関 口 温 朗 昭和 40 年 5 月生。平成 6 年京都大学大学院工 学研究科数理工学専攻修士課程修了。現在、大学共同利用機関法 人 ・ 自然科学研究機構 - 核融合科学研究所に勤務。技術部装置技 術課にて、主に低温関係の業務に従事。低温工学協会会員。

大 場 恒 揮 昭和 46 年 10 月生。平成 6 年 3 月愛知工業大学 機械工学科卒業。同年 4 月より核融合科学研究所技術部装置技術 課に所属。現在に至る。

今 川 信 作 昭和 36 年 1 月 17 日生。昭和 58 年京都大学 工学部原子核工学科卒業。同年 4 月(株)日立製作所入社。平成 3 年 4 月核融合科学研究所大型ヘリカル研究部助手、平成 9 年 10 月 同助教授、平成 16 年 4 月同教授。主として大型超伝導コイルと極 低温構造物に関する研究に従事。低温工学協会、プラズマ核融合 学会会員。博士 (工学)。 